\title{
Phosphate availability and the ultimate control of new nitrogen input by nitrogen fixation in the tropical Pacific Ocean
}

\author{
T. Moutin ${ }^{1}$, D. M. Karl ${ }^{2}$, S. Duhamel ${ }^{1}$, P. Rimmelin ${ }^{1}$, P. Raimbault ${ }^{1}$, B. A. S. Van Mooy ${ }^{3}$, and H. Claustre ${ }^{4}$ \\ ${ }^{1}$ Laboratoire d'Océanographie et de Biogéochimie, UMR-CNRS 6535, Campus de Luminy, 13288 Marseille Cedex 09, \\ France \\ ${ }^{2}$ Department of Oceanography, University of Hawaii, Honolulu, HI 96822, USA \\ ${ }^{3}$ Department of Marine Chemistry and Geochemistry, Woods Hole Oceanographic Institution, Massachusetts, MA 02543, \\ USA \\ ${ }^{4}$ Laboratoire d'Océanographie de Villefranche, CNRS-INSU and UPMC, BP 08, 06238 Villefranche-sur-mer, France
}

Received: 19 July 2007 - Published in Biogeosciences Discuss.: 26 July 2007

Revised: 30 November 2007 - Accepted: 13 December 2007 - Published: 29 January 2008

\begin{abstract}
Due to the low atmospheric input of phosphate into the open ocean, it is one of the key nutrients that could ultimately control primary production and carbon export into the deep ocean. The observed trend over the last 20 years has shown a decrease in the dissolved inorganic phosphate (DIP) pool in the North Pacific gyre, which has been correlated to the increase in di-nitrogen $\left(\mathrm{N}_{2}\right)$ fixation rates. Following a NW-SE transect, in the Southeast Pacific during the early austral summer (BIOSOPE cruise), we present data on DIP, dissolved organic phosphate (DOP) and particulate phosphate $(\mathrm{PP})$ pools along with DIP turnover times $\left(\mathrm{T}_{\mathrm{DIP}}\right)$ and $\mathrm{N}_{2}$ fixation rates. We observed a decrease in DIP concentration from the edges to the centre of the gyre. Nevertheless the DIP concentrations remained above $100 \mathrm{nmol} \mathrm{L}^{-1}$ and $\mathrm{T}_{\mathrm{DIP}}$ was more than 6 months in the centre of the gyre; DIP availability remained largely above the level required for phosphate limitation to occur and the absence of Trichodesmium spp and low nitrogen fixation rates were likely to be controlled by other factors such as temperature or iron availability. This contrasts with recent observations in the North Pacific Ocean at the ALOHA station and in the western Pacific Ocean at the same latitude (DIAPALIS cruises) where lower DIP concentrations $\left(<20 \mathrm{nmol} \mathrm{L}^{-1}\right)$ and $\mathrm{T}_{\mathrm{DIP}}<50 \mathrm{~h}$ were measured during the summer season in the upper layer. The South Pacific gyre can be considered a High Phosphate Low Chlorophyll (HPLC) oligotrophic area, which could potentially support high $\mathrm{N}_{2}$ fixation rates and possibly carbon dioxide sequestration, if the primary ecophysiological controls, temperature and/or iron availability, were alleviated.
\end{abstract}

Correspondence to: T. Moutin

(thierry.moutin@univmed.fr)

\section{Introduction}

New nitrogen $(\mathrm{N})$ input by $\mathrm{N}_{2}$ fixation has been recognized as a significant process influencing global oceanic productivity and the associated carbon fluxes (Karl et al., 1997; Falkowski, 1997). It is the primary process responsible for the input of N-containing compounds into the sea (Codispoti et al., 2001; Capone and Knapp, 2007) and can decouple $\mathrm{N}$ from other bioelement cycles which depend on ocean mixing; this decoupling has potentially important biogeochemical implications (Gruber, 2004; Karl, 2007). This input largely depends on the biomass of $\mathrm{N}_{2}$ fixing organisms, which in turn depends on factors such as temperature (Capone et al., 1997; Staal et al., 2003; Breitbarth et al., 2007), iron (Falkowski, 1997; Kustka et al., 2002; Fu and Bell, 2003) and P availability (Karl et al., 1997; SanudoWilhelmy et al., 2001; Moutin et al., 2005; Karl et al., in press). These factors are affected by human activity (increase in temperature, increase in nutrient input by rivers and changes in atmospheric Fe input, Tagliabue et al., 2007), so the input of $\mathrm{N}$, via $\mathrm{N}_{2}$ fixation, may change over time. Indeed, Karl et al. (1997) have observed an increase in diazotrophic biomass at the ALOHA station, in the Subtropical North Pacific gyre, along with a decrease in soluble reactive $\mathrm{P}$ (SRP which is equivalent to DIP in our study) and an apparent shift from $\mathrm{N}$ limitation to P limitation (Karl et al., 2001; Karl, 2007).

$\mathrm{P}$ availability is a crucial factor in controlling the process of $\mathrm{N}_{2}$ fixation. It has long been considered, by "geochemists", as the ultimate factor controlling primary production in the global ocean (Redfield et al., 1963; Tyrrell, 1999). Contrary to N, there is a negligible atmospheric reservoir of $\mathrm{P}$ so there is no alternative source when $\mathrm{P}$ runs out. Furthermore, $\mathrm{P}$ availability in the open ocean is probably less affected by human activity. $\mathrm{P}$ coming into the sea is mainly of river origin (Broecker and Peng, 1982). Riverine fluxes of

Published by Copernicus Publications on behalf of the European Geosciences Union. 


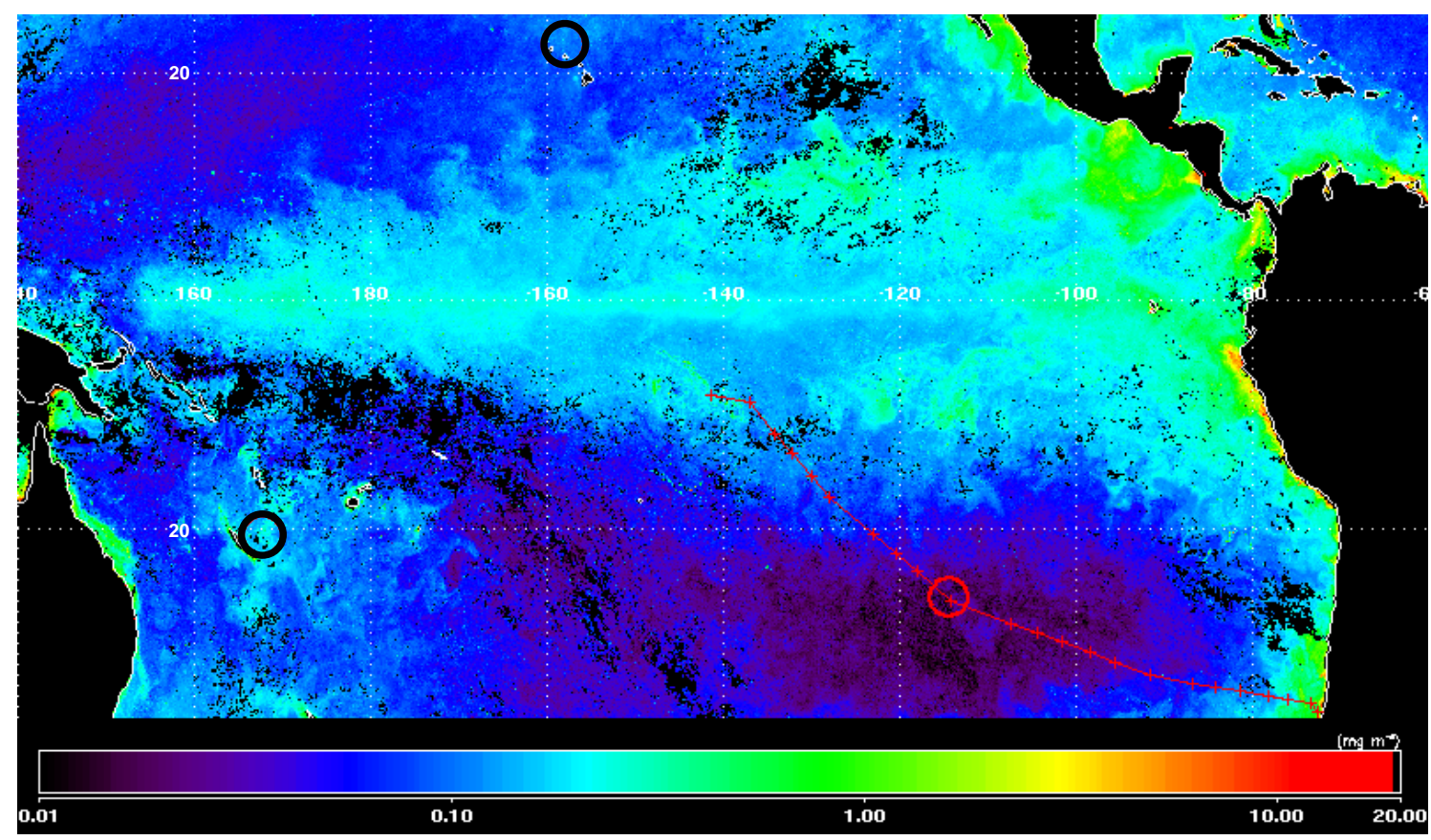

Fig. 1. Location of the stations sampled during the BIOSOPE cruise (November-December 2004) and of the three stations (red circle) where current P pools and availability are compared: a station in the centre of the South gyre (S-gyre station), ALOHA station frequently sampled since the 80's (N-gyre station) and a station sampled during the DIAPALIS cruises (2001-2002) in the SW Pacific Ocean (SW station).

$\mathrm{P}$ are also increasing (Meybeck, 1993; Moutin et al., 1998), however, due to its rapid consumption by biological or chemical processes in estuaries (Lucotte and Danglejan, 1988; Golterman and de Oude, 1991), P input by rivers, may have little impact on a global scale, at least over a decadal time scale. Most $\mathrm{P}$ is trapped in the superficial sediment (Van Den Broeck and Moutin, 2002; Paytan and McLaughlin, 2007) and may only have local impact. Thus, it is necessary to determine the current $\mathrm{P}$ availability in the open ocean to determine its role in the control of $\mathrm{N}_{2}$ fixation, at the present time and in the near future.

We studied $\mathrm{N}_{2}$ fixation, $\mathrm{P}$ pools and subsequent nutrient availability for planktonic species, following a NWSE transect in the South Pacific Ocean during NovemberDecember 2004 (BIOSOPE cruise). $\mathrm{N}_{2}$ fixation rate, and DIP, DOP and PP pools were measured together with DIP turnover times in the upper water column. Data from this cruise, particularly from the central gyre, which is one of the least studied major oceanic entities of the worlds ocean, is compared with data obtained from the North Pacific gyre at the ALOHA station and a station in the South Western Pacific, where blooms of the $\mathrm{N}_{2}$ fixing cyanobacterium Trichodesmium, are frequently observed (Dupouy et al., 2000). Other diazotrophs such as the recently described unicellular cyanobacteria (Zehr et al., 2001; Zehr et al., 2007) further emphasise the importance of the $\mathrm{N}_{2}$ fixation process in the budget of new N. Nevertheless, current estimates suggest that Trichodesmium may be two- to threefold more abundant than previously reported and may account for the missing sink of $\sim 90 \mathrm{Tg} \mathrm{N}$ required to support the observed new production in the ocean (Davis and McGillicuddy, 2006; Levitan et al., 2007) and confirms the prevalent role of Trichodesmium previously reported "in the oligotrophic ocean" (Capone et al., 1997). We consider the current understanding of the factors controlling $\mathrm{N}_{2}$ fixing organism biomass and the most probable temporal evolution of these factors, then discuss the predictable changes that may occur in $\mathrm{N}_{2}$ fixation and DIP availability in the south equatorial Pacific.

\section{Methods}

2.1 Station locations, cruises, chronology and sample collection

The BIOSOPE cruise was carried out during NovemberDecember 2004 from the Marquesas Islands to the Chilean coast (Fig. 1). We sampled water along a $6000 \mathrm{~km}$ transect and the clearest ocean waters, near Easter Island (Morel et al., 2007) inside the South East Pacific gyre suggested to be the most oligotrophic and stable water body on the basis of remotely sensed ocean colour (Claustre and Maritorena, 2003). All samples were collected from a CTD rosette fitted with 20,12-L Niskin bottles equipped with silicone rubber closures and tubing that had been carefully cleaned to avoid introducing toxic metals during sampling. Following water collection, samples were processed within $1 \mathrm{~h}$. 
Table 1. SST range $\left({ }^{\circ} \mathrm{C}\right.$, monthly long-term mean data), and integrated $\left(0-100 \mathrm{~m}\right.$ integrals) $\mathrm{P}$ pools $\left(\mathrm{mmol} \mathrm{m}^{-2}\right)$ at the three studied stations. N-gyre (ALOHA station, http://www.soest.hawai.edu) and SW station (Chenal des Loyauté station, http://www.com.univ-mrs.fr/ IRD/urcyano/identite/spdiap.htm). *NOAA_OI_SST_V2 data provided by the NOAA/OAR/ESRL PSD, Boulder, Colorado, USA, from their Web site at http://www.cdc.noaa.gov/

\begin{tabular}{lllll}
\hline & SW station & N-gyre station (ALOHA) & S-gyre station \\
\hline & & $21^{\circ} 30 \mathrm{~S} ; 167^{\circ} \mathrm{E}$ & $22^{\circ} 45 \mathrm{~N} ; 158^{\circ} \mathrm{W}$ & $26^{\circ} 05 \mathrm{~S} ; 114^{\circ} \mathrm{W}$ \\
SST $\left({ }^{\circ} \mathrm{C}\right)$ range* & Min-Max & $23.1-27.3$ & $23.4-26.4$ & $20,7-25,1$ \\
I DIP $(0-100 \mathrm{~m})$ & Winter-Summer & $9.65-5.40$ & $5.07-5.06$ & 12.45 \\
I DOP $(0-100 \mathrm{~m})$ & Winter-Summer & $26.45-21.35$ & $21.66-23.69$ & 16.28 \\
I PP $(0-100 \mathrm{~m})$ & Winter-Summer & $1.97-1.52$ & $1.44-1.33$ & 0.54 \\
\hline
\end{tabular}

Data from the central station, inside the South Pacific gyre (S-gyre station), are compared with data obtained from the DIAPALIS cruises, at the chenal des Loyauté station (SW station) in 2002-2003, and data from the ALOHA station (N-gyre station) in the North Pacific in 2000-2001 (Table 1 and Fig. 1).

\subsection{Analytical methods}

\subsection{1 $\mathrm{N}_{2}$ fixation rate}

One $\mathrm{mL}$ of ${ }^{15} \mathrm{~N}_{2}$ gas (99\% ${ }^{15} \mathrm{~N}_{2}$ EURISOTOP) was introduced to each $0.6 \mathrm{~L}$ polycarbonate bottle through a Teflonlined butyl rubber septum using a gas-tight syringe, following the protocol of Montoya et al. (1996). Following $24 \mathrm{~h}$ incubations, the samples were filtered under low vacuum $(100 \mathrm{~mm} \mathrm{Hg})$ through precombusted $\left(24 \mathrm{~h}\right.$ at $\left.450^{\circ} \mathrm{C}\right)$ $25 \mathrm{~mm} \mathrm{GF} / \mathrm{F}$ filters and dried at $60^{\circ} \mathrm{C}$. Filters were stored in a desiccator until processed. Determination of ${ }^{15} \mathrm{~N}$ enrichments were performed using an Integra-CN PDZ EUROPA mass spectrometer. We measured a background natural abundance, determined from 8 unlabelled samples, of $0.367 \pm 0.007 \%$. Only excess enrichments higher than two times the standard deviation $(0.014 \%$ for $\mathrm{N})$ were considered significant. As we worked with low levels of particulate $\mathrm{N}$ (PN), we calibrated the spectrometer using the same conditions as for PN and the quality of the analysis was tested with standard molecules (glycine). Based on the lowest $\mathrm{N}$ level determined by our mass spectrometer $(0.2 \mu \mathrm{mol})$, the detection limit for $\mathrm{N}_{2}$ fixation was $0.12 \mathrm{nmol} \mathrm{L}^{-1} \mathrm{~d}^{-1}$. $\mathrm{N}_{2}$ fixation rates $\left(\mathrm{nmol} \mathrm{L} \mathrm{L}^{-1} \mathrm{~d}^{-1}\right.$ ) were computed from an equation based on final PN (Dugdale and Wilkerson, 1986). A detailed description of the methodologies for ${ }^{15} \mathrm{~N}$ based measured rates including $\mathrm{N}_{2}$ fixation rates is given in the paper of Raimbault and Garcia (2007).

\subsubsection{P pools}

Total P (TP) in seawater samples may be separated in three pools: the Dissolved Inorganic P (DIP) pool, the Dissolved Organic P (DOP) pool and the Particulate P (PP) pool.
The DIP pool was estimated on board using the molybdenum blue reaction (Strickland and Parsons, 1972), on $50 \mathrm{~mL}$ samples, using a $10 \mathrm{~cm}$ length-cuvette in a spectrophotometer (Cecil CE 1011), at $880 \mathrm{~nm}$, following a 30 min reaction time. Concentrations were expressed in $\mathrm{nmol} \mathrm{L}^{-1}$. The lower limit of detection for DIP by this method was $20 \mathrm{nmol} \mathrm{L}^{-1}$. Only one sample was analysed per depth with the exception of the S-gyre station where triplicate samples were analysed. The new MAGIC 25 procedure (Rimmelin and Moutin, 2005) was used on triplicate samples to determine DIP concentration (detection limit $=0.8 \pm 0.5 \mathrm{nmoll}^{-1}$ ) and arsenate concentration at the S-gyre station. The arsenate concentration was $10.8 \mathrm{nmol} \mathrm{L}^{-1}(\mathrm{sd}=8.6, \mathrm{n}=21)$. Because this is lower than the detection limit outlined in the Strickland and Parsons (1972) procedure for DIP measurement and is not constant (relatively high standard deviation), no arsenate correction was taken into account for DIP measurement.

The PP pool was determined by the filtration of 1-L samples through polycarbonate filters $(0.2 \mu \mathrm{m} ; 47 \mathrm{~mm})$ at very low pressure. Pressure was increased to get a drop by drop filtration but never exceeded 0.1 bar. PP was measured by standard DIP analysis at $880 \mathrm{~nm}$, following high temperature persulfate wet-oxidation at $120^{\circ} \mathrm{C}$ and 1 bar (Pujopay and Raimbault, 1994) which converts all inorganic and organic non-reactive P compounds to DIP. Only one sample was analysed per depth with the exception of the S-gyre station where duplicate samples were analysed. Using a concentration factor of 40 (final volume $=25 \mathrm{~mL}$ ), the detection limit was $0.5 \mathrm{nmol} \mathrm{L}^{-1}$.

Total P (TP) was estimated from $40 \mathrm{~mL}$ duplicate seawater samples, using the same high-temperature persulfate wetoxidation pre-treatment as for PP. DIP was then analysed as previously described. The measurement of DOP in seawater requires simultaneous measurements of DIP and TP. DOP was assumed to be equal to ([TP] $-[\mathrm{DIP}+\mathrm{PP}])$. The precision and accuracy of the DOP estimates decreased with increasing depth, as DIP concentrations became the dominant component in the total dissolved nutrient pools. 


\subsubsection{Turnover times of DIP}

The DIP turnover time ( $\mathrm{T}_{\mathrm{DIP}}$ ) is the ratio of DIP concentration to DIP uptake rate. Thingstad et al. (1993) derived the following relationship for $T_{D I P}: r(t)=1-e^{-t / T}$, where $r$ is the fraction of added radioactivity absorbed, $t$ the incubation time and $\mathrm{T}$ the turnover time. This equation has been rearranged in order to give a direct calculation for turnover time: $\mathrm{T}=-\mathrm{t} / \ln (1-\mathrm{R}(\mathrm{t}))$ where $\mathrm{R}(\mathrm{t})=\left(\mathrm{R}_{f}-\mathrm{R}_{b}\right) / \mathrm{R}_{t}, \mathrm{R}_{f}$, the radioactivity on the filter, $\mathrm{R}_{b}$, the radioactivity of the blank, and $\mathrm{R}_{t}$, total tracer added. $\mathrm{T}_{\mathrm{DIP}}$ was determined using ${ }^{33} \mathrm{P}$ tracer $\left(\mathrm{H}_{3} \mathrm{PO}_{4}\right.$ in dilute hydrochloric acid; Amersham BF 1003; specific activity $>3000 \mathrm{Ci} \mathrm{mmol}^{-1}$ ). The working solution of ${ }^{33} \mathrm{P}$-DIP was prepared by diluting the tracer in Milli$\mathrm{Q}$ water filtered through pre-washed $0.2 \mu \mathrm{m}$ filters, immediately before use. $300 \mathrm{~mL}$ of seawater was dispensed into acid-washed Milli-Q and sample rinsed polycarbonate bottles, and incubated with $25 \mu \mathrm{Ci}$ carrier-free ${ }^{33} \mathrm{PO}_{4}$ working solution to give a total activity of $0.08 \mu \mathrm{Ci} \mathrm{mL}^{-1}$. Less than $0.03 \mathrm{nmol} \mathrm{L}^{-1}$ of $\mathrm{P}$ was added to each sample. The bottles were then placed in an on-deck incubator and maintained at constant temperature using a continuous circulation of surface seawater, at 50, 25, 15, 7, 3 and 1\% incident light. The same protocol was used for duplicate $300 \mathrm{~mL}$ samples where $300 \mu \mathrm{L} \mathrm{HgCl}_{2}\left(20 \mathrm{~g} \mathrm{~L}^{-1}\right)$ had been added as a control for non-biological uptake. Incubations were stopped by the addition of $600 \mu \mathrm{L}$ of non-radioactive $\mathrm{KH}_{2} \mathrm{PO}_{4}(10 \mathrm{mmol}$ $\mathrm{L}^{-1}$ ). The optimal incubation time (4 to $5 \mathrm{~h}$ ) was determined from a prior time-series experiment. Sample counts were at least 10 times greater than the blanks, less than $10 \%$ of the radioactivity in the samples was consumed, and incubations did not exceed several hours in order to minimize the increase in bacterial production caused by confinement (Van Wambeke et al., 2007). DIP turnover times were measured in $50 \mathrm{~mL}$ duplicate sub-samples from each bottle. Filtrations were carried out on $25 \mathrm{~mm}$ polycarbonate filters $(0.2 \mu \mathrm{m})$, placed on DIP-saturated support GF/F filters, using a low-vacuum pressure $<0.2$ bars. Filters were not washed with filtered seawater at the end of the filtration, but pressure was briefly increased to 0.6 bars, to remove non cellular radioactivity from the filter. Filters were then placed in low-potassium $6 \mathrm{~mL}$ glass scintillation vials (Wheaton) with $6 \mathrm{~mL}$ of scintillation liquid (Ultima gold MV, Packard) and the radioactivity of the filters measured using a scintillation counter Packard Tri-Carb® 2100TR. Initial radioactivity was measured on 5 replicates of $5 \mu \mathrm{L}$ of working solution alongside each experiment in order to verify the amount of ${ }^{33} \mathrm{P}$ added to each sample.

\subsubsection{Labile DOP}

We used the Strickland and Parsons (1972) procedure to measure the labile DOP within the gyre. This pool was assumed to be composed mainly of $\mathrm{P}$ monoesters and thus, to be easily hydrolysed by alkaline phosphatase. At each station from the
NW edge to the centre of the gyre, $50 \mathrm{~mL}$ triplicate surface (50\% of incident light depth) samples were incubated with $1 \mathrm{~mL}$ of a fresh and pure solution of Escherichia coli alkaline phosphatase (Sigma P-4252, $0.2 \mathrm{U} \mathrm{mL}^{-1}$ ) and $1 \mathrm{~mL}$ of Tris buffer solution $0.5 \mathrm{M}(\mathrm{pH}=8)$. Following $2 \mathrm{~h}$ incubation at $30^{\circ} \mathrm{C}$, the DIP concentration was measured. A further set of triplicate surface samples was used to determine the initial DIP concentration. The labile DOP concentration is the difference between these two measurements. For each series of measurements, a blank sample was processed as well as a control with $1 \mu \mathrm{mol} \mathrm{L}{ }^{-1}$ of a glucose-6-phosphate solution in order to confirm enzymatic efficiency.

\subsubsection{Excess DIP relative to nitrate concentration}

Ambient nitrate + nitrite and nitrite were measured immediately on collection by pumping the sample from the sampling polyethylene bottle directly through the Technicon AutoAnalyzer. Nitrate and nitrite concentrations in the nanomolar range (lower detection, $3 \mathrm{nmol} \mathrm{L}^{-1}$ ) were obtained using the sensitive method of Raimbault et al. (1990). For submicromolar concentrations, the classical Technicon AutoAnalyser method was used (Tréguer and LeCorre, 1975). The recently defined variable $\mathrm{P}^{*}$ (Deutsch et al., 2007) was calculated: $\mathrm{P}^{*}=\mathrm{PO}_{4}-\mathrm{NO}_{3} / \mathrm{rr}\left(\mathrm{rr}=\right.$ Redfield ratio=16), $\mathrm{PO}_{4}=\mathrm{DIP}$ in this study. While nutrient uptake by non- $\mathrm{N}_{2}$-fixing organisms will on average consume $\mathrm{NO}_{3}$ and $\mathrm{PO}_{4}$ in a proportion that conserves $\mathrm{P}^{*}, \mathrm{~N}_{2}$ fixation will extract $\mathrm{PO}_{4}$ alone, driving a water parcel towards lower P* (Deutsch et al., 2007).

\section{Results}

\subsection{P pools and availability in the tropical Pacific Ocean}

\subsubsection{Spatial distribution (SE Pacific Ocean)}

DIP, DOP and PP concentrations in surface waters were highest near the Marquesas Islands and near the Chilean coast (Fig. 2a, b, c). For the 3 distinct pools, there is an obvious decrease in concentration from the edge to the centre of the gyre, reaching minimum values of 120 and $150 \mathrm{nmol} \mathrm{L}^{-1}$ for the DIP and DOP pools respectively, and less than $10 \mathrm{nmol} \mathrm{L}^{-1}$ for PP. Duhamel et al. (2007) have argued that the PP pool is mainly associated with living biomass in the centre of the gyre. Values of PP less than $10 \mathrm{nmol} \mathrm{L}^{-1}$ suggest extremely low biomass as confirmed by total chlorophyll a (TChla) concentrations reaching $0.017 \mathrm{mg} \mathrm{m}^{-3}$ in surface waters in the centre of the gyre (Ras et al., 2007). In the upper layer from the edge to the centre of the gyre, the decreases in DIP and PP concentrations are approximately one order of magnitude, compared to a factor of 2.5 for the DOP pools. The DIP/DOP concentration ratio is close to one in the centre of the gyre. The mean labile DOP concentration ( $\mathrm{P}$ monoesters) inside the gyre at 5 meter depth was below the detection limit of $20 \mathrm{nmol} \mathrm{L}^{-1}$. DIP turnover 


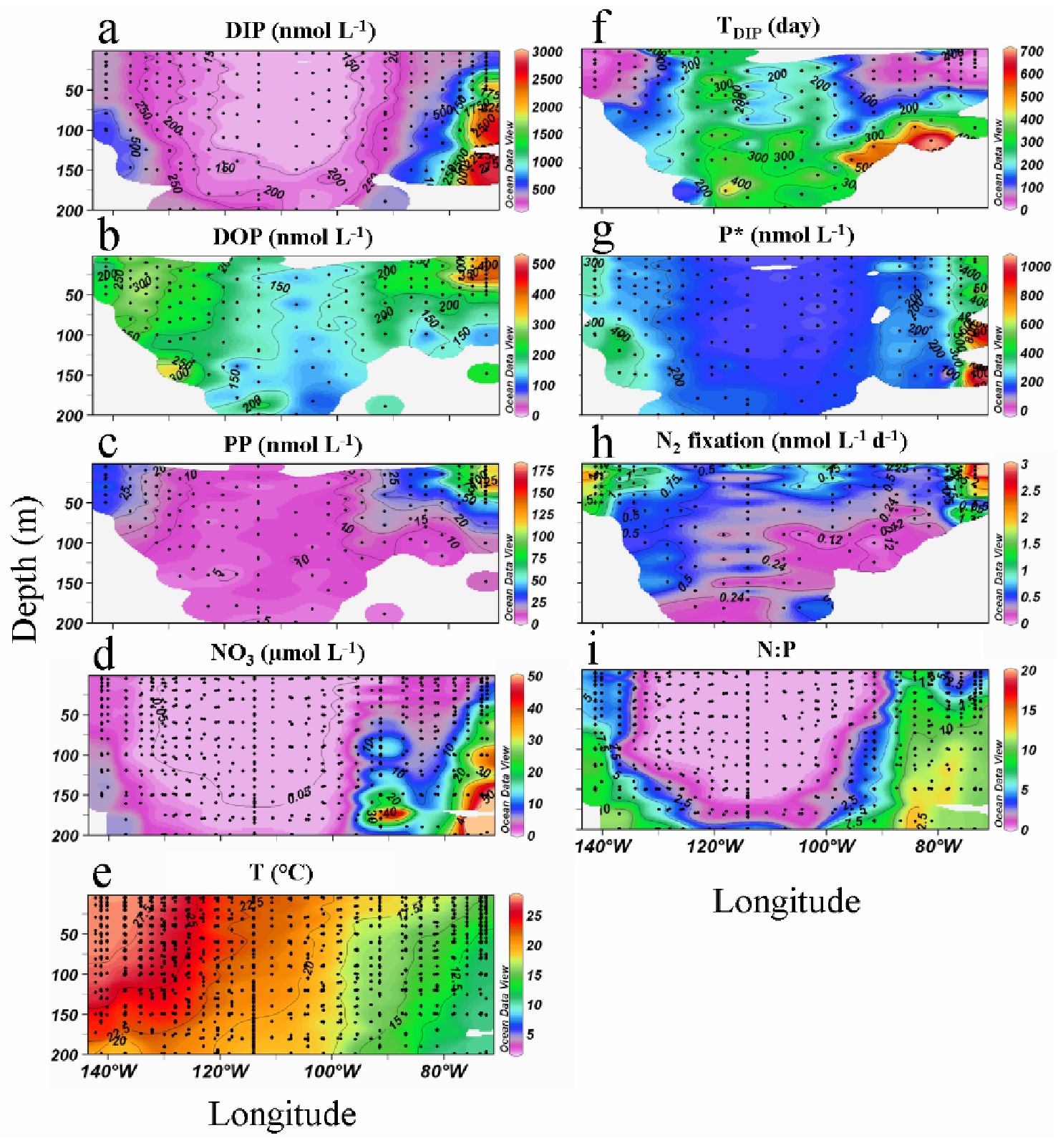

Fig. 2. (a) DIP, (b) DOP, (c) PP, (d) $\mathrm{NO}_{3}^{-}$, (e) Temperature, (f) DIP turnover time, (g) $\mathrm{P}^{*}$, (h) $\mathrm{N}_{2}$ fixation rates and (i) $\mathrm{NO}_{3}^{-} / \mathrm{DIP}$ measured during the BIOSOPE cruise (November-December 2004) in the South Pacific between the Marquesas Islands and the Chilean coast. ODV (Schlitzer, 2002) was used to generate the distribution maps.

times varied from several days at the edge, to around 200 days in the gyre (Fig. 2f). Higher $P^{*}$ values were observed near the Chilean coast below $100 \mathrm{~m}$ depth $\left(\sim 1000 \mathrm{nmol} \mathrm{L}^{-1}\right)$ and close to the Marquesas Islands $\left(\sim 500 \mathrm{nmol} \mathrm{L}^{-1}\right)$. Values of less than $200 \mathrm{nmol} \mathrm{L}^{-1}$ were observed in the centre of the South Pacific gyre (Fig. 2g) where the nitrate concentrations became $<50 \mathrm{nmol} \mathrm{L}^{-1}$ (Fig. 2d). A significant relationship $(\mathrm{p}<0.001$; non parametric Pearson test) was obtained between $\mathrm{N}_{2}$ fixation and $\mathrm{P}^{*}\left(\mathrm{~N}_{2}\right.$ fixation=6.37 $\left.\mathrm{P} *-0.41, \mathrm{~N}=136, \mathrm{r}^{2}=0.49\right)$ using all data collected during the BIOSOPE cruise.

\subsubsection{Vertical depth profile inside the gyre (S-gyre station)}

DIP concentrations are homogeneous having a mean value of $127.0 \mathrm{nmol} \mathrm{L}^{-1}(\mathrm{sd}=7.1, \mathrm{n}=42)$ in the surface waters $(0$ $150 \mathrm{~m}$ ) and increasing with depth below $150 \mathrm{~m}$ (Fig. 3f) at the $\mathrm{S}$-gyre station. The DIP concentration versus depth gradient between 150 and $250 \mathrm{~m}$ is $3.5 \mu \mathrm{mol} \mathrm{m}^{-4}$. DIP concentrations in surface waters are above the detection limits of the standard method (Strickland and Parsons, 1972). No significant difference was observed with the high sensitivity MAGIC 25 method (Rimmelin and Moutin, 2005) thus enabling us to 

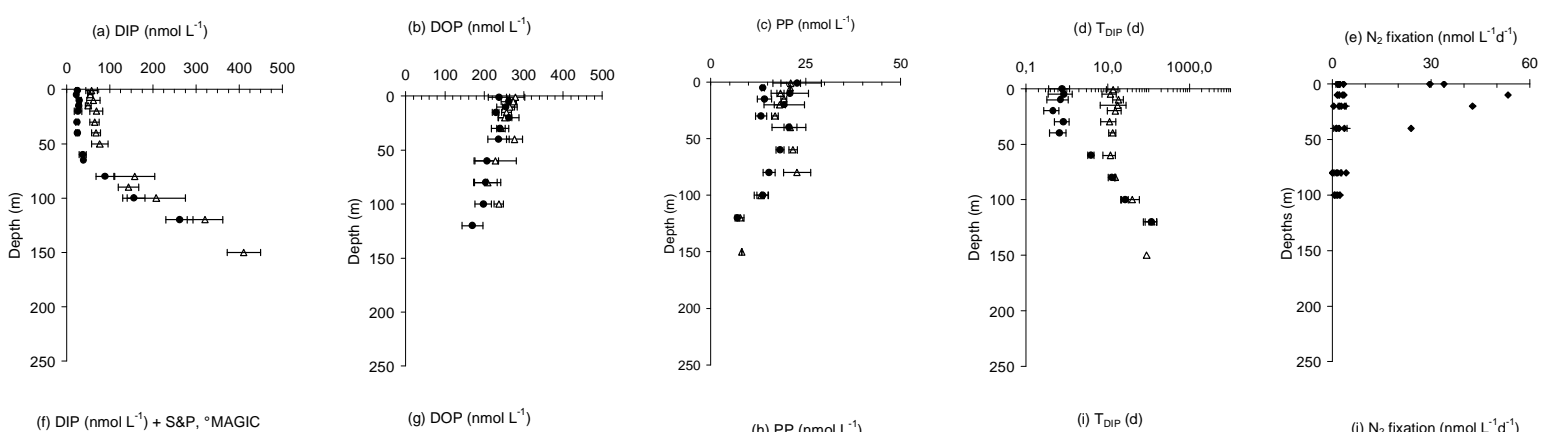

sw
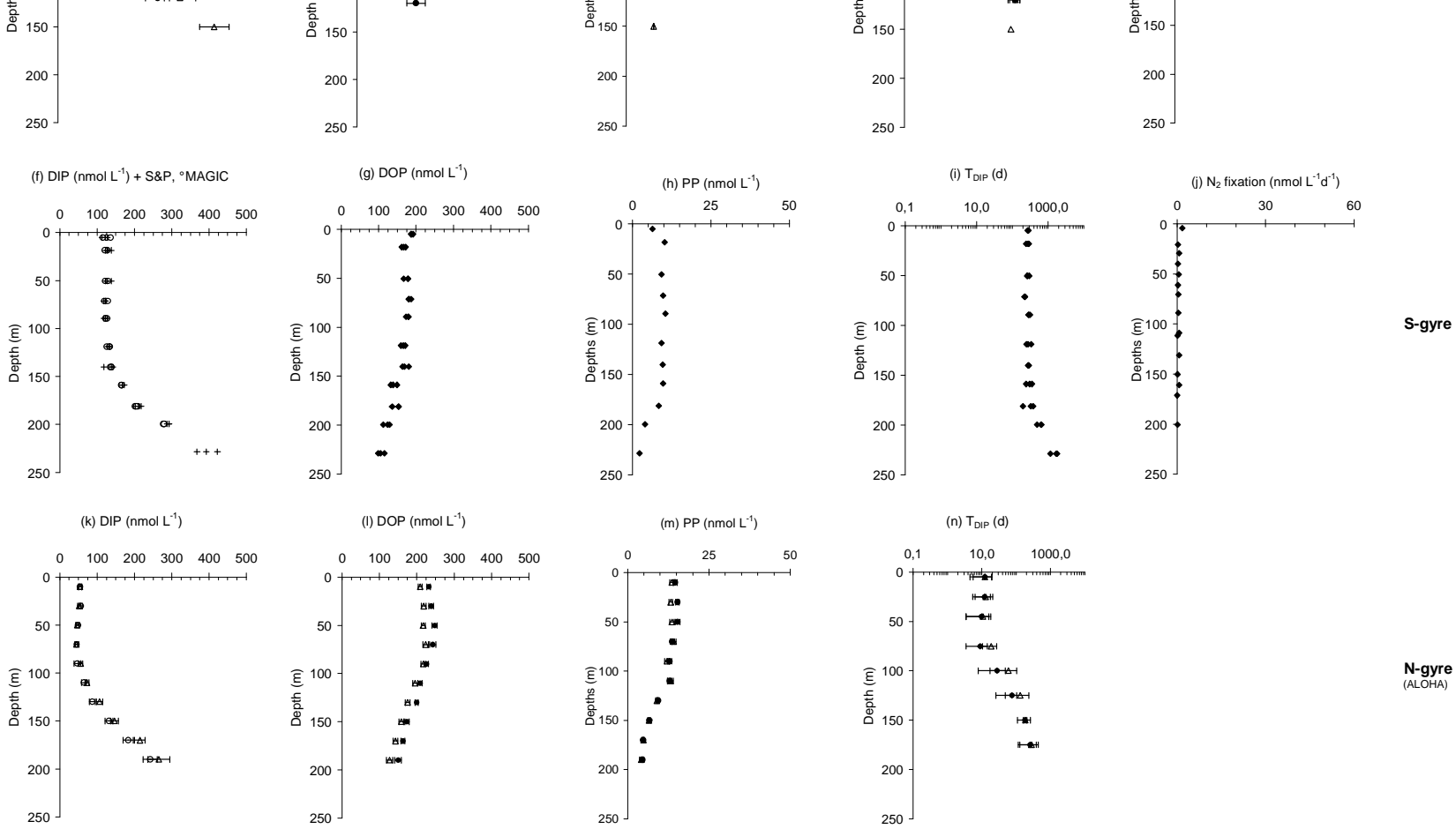

Fig. 3. Current Dissolved Inorganic P (DIP), Dissolved Organic P (DOP), Particulate P (PP) concentrations, DIP turnover time and $\mathrm{N}_{2}$ fixation rates vs depth at the three stations studied in the South, N-gyre (ALOHA station, http://www.soest.hawaii.edu/HOT_WOCE/ftp. html) and SW station (Chenal des Loyauté station, http://www.com.univ-mrs.fr/IRD/urcyano/identite/spdiap.htm). Summer and Winter ( $\Delta$ ) concentrations are indicated when available.

validate our detailed protocol for a 25 times MAGIC preconcentration procedure. DIP turnover times are homogeneous with a mean value of 273 days $(s d=29, n=21)$ in surface waters (Fig. 3i).

DOP concentrations are highest in near surface waters with a mean value of $175.5 \mathrm{nmol} \mathrm{L}^{-1}(\mathrm{sd}=9.2, \mathrm{n}=21)$ and decrease with increasing water depth (Fig. 3g). DOP dominates in the surface water, accounting for $58 \%$ of the total dissolved P pool. DIP becomes the dominant component of the total dissolved pool below $150 \mathrm{~m}$. The mean DOP concentration from duplicate deep water samples $(600-2000 \mathrm{~m})$ is $61.0 \mathrm{nmol} \mathrm{L}^{-1}(\mathrm{sd}=16.5, \mathrm{n}=8)$. PP concentrations follow the same pattern as DOP concentrations with a mean value of $9.3 \mathrm{nmol} \mathrm{L}^{-1}(\mathrm{sd}=1.5, \mathrm{n}=6)$ in surface waters decreasing as water depth increased (Fig. 3h). A maximum in PP was not observed at the depth of the deep chlorophyll maximum $(180 \mathrm{~m})$. Values below $200 \mathrm{~m}$ were similar to the mean concentration from duplicate deep water samples (600-2000 m) of $1.0 \mathrm{nmol} \mathrm{L}^{-1}(\mathrm{sd}=0.3, \mathrm{n}=8)$.

\subsubsection{Comparison with depth profiles from the SW and N- gyre Pacific stations}

In the upper layer, the maximum values of DIP and for $\mathrm{T}_{\mathrm{DIP}}$ are recorded at the S-gyre station. Depths trends similar to those at the S-gyre station, are observed for DIP, DOP and $\mathrm{PP}$ at the SW (Fig. 3a, b, c) and N-gyre (Fig. 3k, 1, m) stations; the only exception is the sharp decrease in DIP concentration, observed at the SW station (Fig. 3a), during the summer period. The average decrease in DIP concentration between austral winter and austral summer in the upper $40 \mathrm{~m}$ of the water column was $35 \mathrm{nmol} \mathrm{L}^{-1}$ at the $\mathrm{SW}$ station. This difference corresponds to a minimum value as DIP concentration was generally below the $20 \mathrm{nmol} \mathrm{L}^{-1}$ detection limit of the classical Strickland and Parsons, 1972 method. No MAGIC measurements are available but indirect estimations of the DIP concentrations from $\mathrm{T}_{\mathrm{DIP}}$ measurements (Van Den Broeck et al., 2004) indicated sub-nanomolar concentrations during the summer period. There was no corresponding increase in either the PP pool or the DOP pool, although large 
differences in the concentration of the DOP pool were observed during both the winter and summer periods. DIP turnover times (Fig. 3d) vary from approximately 10 days in winter to a few hours in summer in near surface waters.

No clear seasonal variations were observed in the DIP pool at the N-gyre station (ALOHA, Fig. 3k). DIP concentrations were lower (by a factor of 2-2.5) than concentrations measured in the mixed layer of the S-gyre station. DOP concentrations were slightly above the DOP concentrations measured at the S-gyre station and very close to those measured at the SW station. The PP concentrations at the N-gyre station were higher (by a factor of 1.5) than those in the more oligotrophic S-gyre station and close to or lower than those at the SW-station. DIP turnover times were around 10 days near the sea surface at the $\mathrm{N}$-gyre station, close to those observed during the winter season at the SW station and no marked variations between the summer and winter seasons are observed.

\subsection{Current distribution of $\mathrm{N}_{2}$ fixation}

The $\mathrm{N}_{2}$ fixation in surface waters during the BIOSOPE cruise yielded maximum values, around $4 \mathrm{nmol} \mathrm{L}^{-1} \mathrm{~d}^{-1}$, near the Chilean coast, intermediate values near the Marquesas Islands $\left(1.2-2.8 \mathrm{nmol} \mathrm{L}^{-1} \mathrm{~d}^{-1}\right)$ and low values, just above the detection limit of the method employed $\left(0.12 \mathrm{nmol} \mathrm{L}^{-1} \mathrm{~d}^{-1}\right)$, inside the gyre (Fig. 2h). Integrated depth profiles gave a value of $\sim 142 \mu \mathrm{mol} \mathrm{N} \mathrm{m}{ }^{-2} \mathrm{~d}^{-1}$ near the Chilean coast ( 1 in situ depth profile between 0 and $40 \mathrm{~m}$ ) and 48 and $135 \mu \mathrm{mol} \mathrm{N} \mathrm{m}{ }^{-2} \mathrm{~d}^{-1}$ at the S-gyre station (2 in situ depth profiles between 0 and $200 \mathrm{~m}$ taken on two days). A doubling of the mean irradiance intensity and similar variations of ammonium and nitrate uptake rates were also observed between the two different days. Maximum $\mathrm{N}_{2}$ fixation rates were found in the upwelling area where N:P ratio close to 10 (Fig. 2i) and ample Fe concentrations (1.2-3.9 nM) are found (Blain et al., 2007), and temperatures did not exceed $16^{\circ} \mathrm{C}$ (Fig. 2e). The $\mathrm{N}_{2}$ fixation rates are maximal near the surface within the gyre and decrease with depth indicating that light could play a role in controlling this process. At present we do not know the species responsible for these fluxes. Trichodesmium, a large filamentous $\mathrm{N}_{2}$ fixing microorganism that often forms large easily identified colonies, was not observed. Bonnet et al. (2007) found the presence of extremely low numbers of Group A cyanobacterial phylotypes (see their Table 2).

The $\mathrm{N}_{2}$ fixation rates at the $\mathrm{SW}$ station (DIAPALIS cruises) were highly variable within seasons and ranged between 151-703 $\mu \mathrm{mol} \mathrm{N} \mathrm{m}^{-2} \mathrm{~d}^{-1}$ (Garcia et al., 2007). The maximum values correspond to a Trichodesmium specific bloom that occurred during the summer period (Fig. 3e) when temperatures were above $26^{\circ} \mathrm{C}$. At the $\mathrm{N}$-gyre station ALOHA, higher $\mathrm{N}_{2}$ fixation rates than those measured in the South Pacific gyre have already been reported and these appear to be associated with Trichodesmium blooms (Dore et al., 2002). At least two independent microbial assemblages and ecosystem processes contribute to $\mathrm{N}_{2}$ fixation in the NP gyre, namely the "background state" wherein a relatively low but relatively constant rate supported by pico and nanodiazotrophs, and the aperiodic "bloom state" wherein large filamentous, colonial and aggregate forming diazotrophs (Trichodesmium and/or endosymbiont-containing diatoms) dominate the new $\mathrm{N}$ cycle (Karl et al., in press). It is estimated that the summer bloom is responsible for up to $38 \%$ of the annual $\mathrm{N}_{2}$ fixation at ALOHA station (J. Dore, personal communication). Based on a variety of independent estimates including nitrogenase activity by acetylene reduction method, Trichodesmium abundance, N:P mass balance, and ${ }^{15} \mathrm{~N}$ isotope balance, an annual $\mathrm{N}_{2}$ fixation rate of $31-51 \mathrm{mmol} \mathrm{N} \mathrm{m}^{-2}$ year $^{-1}$ was estimated for the Pacific Ocean near Hawaii (Karl et al., 1997). $\mathrm{N}_{2}$ fixation at Station ALOHA would equate to $3-4 \%$ of the total $\mathrm{N}$ demand for the microorganisms that inhabit that ecosystem. However, when compared to estimates of new production or to $\mathrm{N}$ exports by sinking particles and migrant zooplankton, $\mathrm{N}_{2}$ fixation appears to be a significant (40-60\%) source of new $\mathrm{N}$ (Karl et al., in press) since export from oligotrophic ecosystems is low. When compared to estimates of new production with ${ }^{15} \mathrm{~N}, \mathrm{~N}_{2}$ fixation accounted for up to $50 \%$ in the South Pacific gyre (Raimbault and Garcia, 2007). The $\mathrm{N}_{2}$ fixation rates measured inside the SP gyre are close to the averaged $0.25 \pm 0.05 \mathrm{nmol} \mathrm{N} \mathrm{L}^{-1} \mathrm{~d}^{-1}$ measured in oligotrophic waters of the NP Ocean where water temperatures are typically below $20-25^{\circ} \mathrm{C}$ (Needoba et al., 2007). Integrated rates in the SP gyre are similar to those reported by Falcon et al. (2004) for the tropical NA in summer $\left(62 \mu \mathrm{mol} \mathrm{N} \mathrm{m}{ }^{-2} \mathrm{~d}^{-1}, \mathrm{SE}=21\right.$, $\mathrm{n}=30)$ and February $2001\left(167 \mu \mathrm{mol} \mathrm{N} \mathrm{m}{ }^{-2} \mathrm{~d}^{-1}, \mathrm{SE}=49\right.$, $\mathrm{n}=30)$ and in the subtropical NP $\left(84 \pm 50 \mu \mathrm{mol} \mathrm{N} \mathrm{m}^{-2} \mathrm{~d}^{-1}\right)$.

\section{Discussion}

\subsection{P availability in the contemporary ocean}

\subsubsection{Availability of DIP}

DIP is directly available for all microbes and its concentration can be considered as the first criterion to evaluate $\mathrm{P}$ availability. DIP is not completely exhausted from the upper water at the N-gyre station (ALOHA) or in the South Pacific gyre, but DIP concentrations reach $<20 \mathrm{nM}$ concentration during the summer season at the SW station. As these DIP concentrations at the SW station are close to or even below detection limits of classical chemical analyses $(20 \mathrm{nM})$, the study of DIP turnover times can provide additional information on nutrient availability: DIP turnover time is the most broadly-applicable measurement of DIP availability because it has the potential to identify variations in $P$ availability even when DIP concentrations become analytically undetectable (Moutin et al., 2002; Moutin et al., 2005). 
Table 2. DIP turnover time (mean and standard deviation in hours) in upper ocean surface waters (0-20 m or at the depth of 50\% of incident light*), D5S1N5 is for 5 depths (D5), 1 station sampled (S1), 5 samples (N5), as an example. **=median value. See also (Tanaka et al., 2006) for others $T_{\text {DIP }}$ measurements in the Mediterranean Sea.

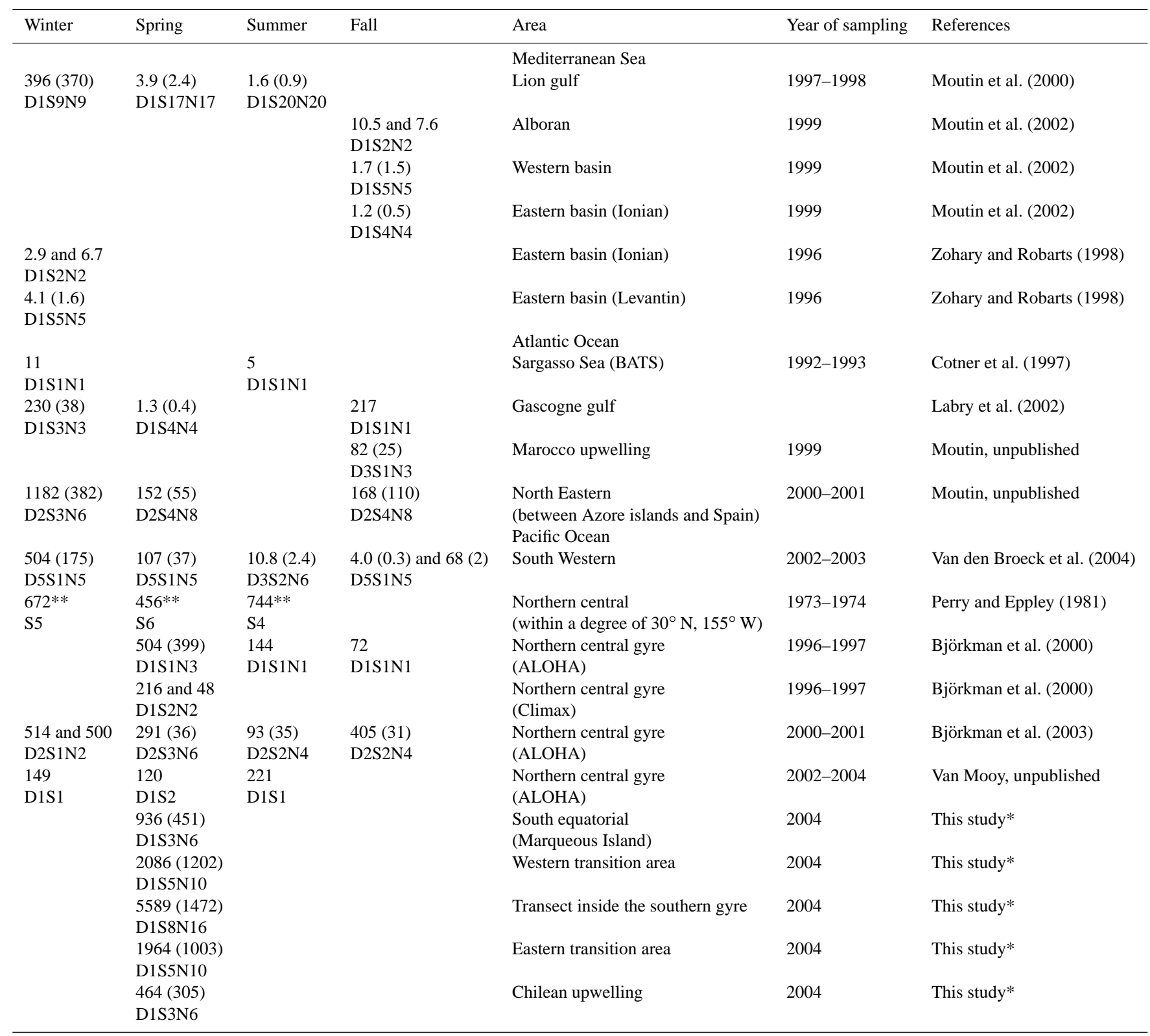

DIP turnover times represent the ratio between DIP concentration and DIP uptake by the microbial assemblage. Despite the DIP concentrations being much lower in the centre of the South gyre than those found near the Marquesas Islands and Chilean coast, the larger $\mathrm{T}_{\mathrm{DIP}}$ indicates that DIP availability, compared to the planktonic species requirement within the gyre, is greater than in the upwelling region. The turnover time is also the time it would take for all the ambient DIP to be taken up assuming no additional input (Ammerman et al., 2003). Without any additional external sources or input by regeneration, it would take 200 days to exhaust all available DIP in the gyre, while it may only take 10 days in the Chilean upwelling and at the $\mathrm{N}$ gyre station (ALOHA). Nonetheless, $\mathrm{T}_{\mathrm{DIP}}$ in the Southern and Northern gyres suggest a P sufficiency that is contrary to what has been observed in the very P-depleted Mediterranean Sea, Sargasso Sea and South Western Pacific during the summer season (Table 2) where $T_{\text {DIP }}$ of less than $10 \mathrm{~h}$ 
were observed (Table 2). Nevertheless, short DIP turnover times of around 2 days (Bjorkman et al., 2000, Table 2) and a long term decrease in DIP availability (Karl et al., 1997; Karl et al., 2001) have also been reported at the ALOHA station. The comparison between DIP turnover times obtained by Perry and Eppley (1981) in the central Pacific gyre in the 70 's, and current estimations (Table 2) confirm the decrease in DIP availability, particularly during the summer season. The large differences in $\mathrm{T}_{\mathrm{DIP}}$ measurements observed in oligotrophic areas (Table 2) enable us to distinguish the High P Low Chlorophyll (HPLC) oligotrophic areas (SP gyre) and Low P Low Chlorophyll (LPLC) oligotrophic areas (Sargasso Sea, Mediterranean Sea). The ALOHA station in the NP gyre appears to be an intermediary or transient state of DIP availability.

\subsubsection{Availability of DIP and $\mathrm{N}_{2}$ fixation}

Low DIP availability may control the growth and biomass of $\mathrm{N}_{2}$ fixing organisms. A critical DIP turnover time of $50 \mathrm{~h}$, giving favourable and unfavourable growth conditions for Trichodesmium, was determined during the DIAPALIS survey in the SW Pacific ocean (Moutin et al., 2005). It was demonstrated that the sharp decrease in DIP availability in the early summer season could explain most of the numerous and periodic sea surface accumulations of Trichodesmium observed, and more importantly, the prevalent role of DIP availability in the control of $\mathrm{N}$ input by $\mathrm{N}_{2}$ fixation in this area (Moutin et al., 2005). The DIP turnover times of around 10 days measured at the N-gyre station (ALOHA, Fig. 3n) suggests a higher $P$ deficiency than in the South Pacific gyre ( $T_{\text {DIP }}$ around 200 days and DIP concentrations $>100 \mathrm{nmol}^{-1}$ ), but this is not strong enough to provoke Trichodesmium decay (obtained for $\mathrm{T}_{\mathrm{DIP}}<50 \mathrm{~h}$ equivalent to DIP concentration $<10 \mathrm{nmol} \mathrm{L}^{-1}$ at the SW station). Thus, another factor must prevent the complete exhaustion of DIP and may currently control $\mathrm{N}_{2}$ fixation by Trichodesmium at the N-gyre station (ALOHA). Nevertheless, episodic Trichodesmium blooms followed by severe DIP depletion have already been observed at the N-gyre station (Letelier, ASLO meeting 2006).

Due to their smaller size, small diazotrophs are probably more efficient in taking up DIP from the surrounding water and as a consequence, are probably less affected by DIP depletion. It is likely that the current high DIP availability in the SP gyre may not control $\mathrm{N}_{2}$ fixation, at least during the studied period (November-December). Strong seasonal variations in DIP availability are not expected as this is an area where the lowest sea surface chlo a concentrations in the world's oceans are determined from space throughout the year (Claustre and Maritorena, 2003).

\subsubsection{Availability of DOP}

For the most part DOP is not directly available to living organisms as it cannot be taken into the cell in this form (Cembella et al., 1984; Bjorkman and Karl, 2003; Paytan and McLaughlin, 2007). Organic P must first be converted to DIP. The labile fraction of the DOP pool inside the South gyre was $<20 \mathrm{nmol} \mathrm{L}^{-1}$ suggesting that only a small fraction of the DOP pool was available (through alkaline phosphatase activity). At the SW station during the summer period, DIP concentrations reached $<20 \mathrm{nmol} \mathrm{L}^{-1}$. However, no significant change was observed in the DOP concentrations (Fig. 3b), which suggests that most of the DOP pool in the upper surface is not readily available, even after several months of severe DIP depletion. Moreover, despite the variations in DIP concentrations and turnover times at all three stations, the DOP concentration was around $200 \mathrm{nmol} \mathrm{L}^{-1}$ at all three suggesting that the DOP reservoir is not a particularly dynamic reservoir of $\mathrm{P}$ in upper ocean waters. The South Pacific gyre appears to be an ocean as close as can be expected (Lewis, personal communication). Thus, the DOP pool in the S-gyre station may mainly be formed by an accumulation of older organic molecules with low bioavailability.

Even though most of the DOP pool is not readily available, it may play a determinant role in phytoplankton growth. It is probable that the turnover of the available DOP pool is rapid. It has been estimated that DOP utilization can be of the same order of magnitude as DIP utilization in the upper water column at ALOHA (Bjorkman and Karl, 2003). Recent evidence also indicates that certain compounds in the DOP pool, particularly the phosphonates, which may account for $25 \%$ of the high molecular weight DOP pool (Clark et al., 1998; Kolowith et al., 2001), may be used (Dyhrman et al., 2006), but we know little about its global significance and there is a major scope for future research in the field of $\mathrm{P}$ availability.

4.1.4 Relative availability of DIP pool vs availability of DIN (DIN: Dissolved Inorganic Nitrogen which is equivalent to nitrate in our study)

$\mathrm{P}^{*}$ is a convenient estimate of the excess in DIP relative to DIN, when it is assumed that these nutrients are utilised following Redfield proportions ( $\mathrm{N}: \mathrm{P}=16)$. $\mathrm{P}^{*}$ variations in the South Pacific are close to those expected by Deutsch et al. (2007). They argue that denitrification in the oxygen minimum zones (OMZs) generates DIP-enriched and DINdeficient waters. These waters subsequently undergo a disproportionate loss of DIP as they are upwelled and transported into the adjacent gyres. The eastern Pacific Ocean near the Chilean coast is one of the three major areas of denitrification in the world's oceans (Codispoti and Richards, 1976). Thus, it may explain the high $\mathrm{P}^{*}$ observed (Fig. 2g). North of $14^{\circ} \mathrm{S}$, the waters are under the influence of the equatorial regime (Claustre et al. this volume). Following 
general circulation models, water near the Marquesas Islands (Fig. 2g) are influenced by waters upwelled near the equator. This may also explain the high $\mathrm{P}^{*}$ values observed in this area. The decrease in $\mathrm{P}^{*}$ toward the centre of the gyre corresponds to the trend observed by Deutsch et al. (2007): downstream of the OMZs, surface waters that initially carry a surplus of phosphorus (because of subsurface denitrification) lose this excess gradually through $\mathrm{N}_{2}$ fixation. This may be attributed to $\mathrm{N}_{2}$ fixation restoring the system to a "Redfieldian" balance as already suggested by Redfield (1934) and Capone and Knapp (2007).

The model by Deutsch et al. (2007) for $\mathrm{N}_{2}$ fixation rates along the studied transect, with minimum values found on the edge and maximum values in the centre of the gyre, is contrary to our observations. They calculated a basin-wide $\mathrm{N}_{2}$ fixation rate for the $\mathrm{Pa}$ cific of $48 \mathrm{mmol} \mathrm{N} \mathrm{m}^{-2} \mathrm{yr}^{-1}$ similar to previous estimates $\sim 50 \mathrm{mmol} \mathrm{N} \mathrm{m}^{-2} \mathrm{yr}^{-1}$, Redfield et al. (1963), with maximum values of up to $120 \mathrm{mmol} \mathrm{N} \mathrm{m}^{-2} \mathrm{yr}^{-1}$ inside the South Pacific gyre. Assuming no seasonal variations (i.e. $120000 / 365 \sim 330 \mu \mathrm{mol} \mathrm{N} \mathrm{m}^{-2} \mathrm{~d}^{-1}$ ) and a maximum depth of $200 \mathrm{~m}$ available for $\mathrm{N}_{2}$ fixation inside the gyre, this rate is equivalent to $1.7 \mathrm{nmol} \mathrm{N} \mathrm{L}^{-1} \mathrm{~d}^{-1}$, a value at least 2.5 times greater than the mean rate measured in this study $\left(0.24\right.$ and $\left.0.67 \mathrm{nmolN} \mathrm{L}^{-1} \mathrm{~d}^{-1}\right)$. The annual rate calculated near the Chilean coast by Deutsch et al. (2007) is under $20 \mathrm{mmol} \mathrm{N} \mathrm{m}^{-2} \mathrm{yr}^{-1}$. Assuming no seasonal variations (i.e. $20000 / 365 \sim 55 \mu \mathrm{mol} \mathrm{N} \mathrm{m} \mathrm{m}^{-2} \mathrm{~d}^{-1}$ ) and a maximum depth of $\sim 40 \mathrm{~m}$ available for $\mathrm{N}_{2}$ fixation in the upwelling, this rate is equivalent to $\sim 1 \mathrm{nmol} \mathrm{N} \mathrm{L}{ }^{-1} \mathrm{~d}^{-1}$, a value that is around 4 times lower than the measured value. Thus, even if the calculated (Deutsch et al., 2007) and observed (Fig. 2g) P* distributions are very similar, the $\mathrm{N}_{2}$ fixation rates measured in the South Pacific gyre are not consistent with the predicted rates. Some of the discrepancy between observed $\mathrm{N}_{2}$ fixation rates and model outputs is certainly due to uncertainties in ocean circulation and care should be taken, also, that the trend suggested by Deutch et al. (2007) may not directly be reflected in a snap shot observation. The strong relationship between $\mathrm{P}^{*}$ and $\mathrm{N}_{2}$ fixation rates observed (Fig. $2 \mathrm{~g}$ and $\mathrm{h}$ ) may further strengthen the idea that biological $\mathrm{N}_{2}$ fixation and marine $\mathrm{N}$ removal are tightly coupled (Deutsch et al., 2007): $\mathrm{N}_{2}$ fixation begins, and is highest, when upwelled waters reach the surface near the Chilean coast. The waters do not need to be transported to the warmer adjacent gyre to loose most of their excess $\mathrm{P} . \mathrm{N}_{2}$ fixation in the surface waters increases the deficit in DIP relative to DIN (decrease in $\mathrm{P}^{*}$ ). However, $\mathrm{N}_{2}$ fixation is not the only process driving the decrease in $\mathrm{P}^{*}$ in the water. The export of material with a N:P ratio lower than the Redfield ratio will give the same pattern. It is not known whether the greater depth of the synthesis of material that is vertically exported outside the upwelling zone produces exported material with a higher $P$ content.

Deutsch et al. (2007) argue that the ratio of $\mathrm{N}$ to $\mathrm{P}$ in seawater may be the central factor regulating $\mathrm{N}_{2}$ fixation and that Fe rich dust may not exert as much influence on marine $\mathrm{N}_{2}$ fixation (Capone and Knapp, 2007) as is currently assumed (Berman-Frank et al., 2001). The close link between denitrification and $\mathrm{N}_{2}$ fixation is convincing but another simple explanation for the higher $\mathrm{N}_{2}$ fixation rates near the Chilean coast could be that there is less competition for nutrients so enabling $\mathrm{N}_{2}$ fixing organisms to thrive independently from the DIN:DIP ratio.

\section{2 $\quad \mathrm{N}_{2}$ fixation distribution and controls other than $\mathrm{P}$ avail- ability}

The remaining relatively high DIP concentration in the centre of the SP gyre suggests a control other than DIP availability for $\mathrm{N}_{2}$ fixation. It is probably related to temperature or $\mathrm{Fe}$ availability. Indeed, the $\mathrm{Fe}$ requirement of $\mathrm{N}_{2}$ fixers must be provided by the upper photic water column and the temperature must be adequate to enable growth or $\mathrm{N}_{2}$ fixation.

\subsubsection{Temperature}

There are numerous studies showing a correlation between Trichodesmium abundance and temperature (Capone et al., 1997; Lugomela et al., 2002; Chen et al., 2003; Moutin et al., 2005). The relationship between Trichodesmium distribution and sea surface temperature (SST) is so "commonly accepted" that the observed temperature distribution range $\left(20-30^{\circ} \mathrm{C}\right)$ is used to constrain $\mathrm{N}_{2}$ fixation in oceanic biogeochemical circulation models (OCBM) (Fennel et al., 2002; Hood et al., 2004). Temperatures above $26^{\circ} \mathrm{C}$ are necessary for Trichodesmium bloom development (Carpenter et al., 2004). The correlation between water temperature and Trichodesmium abundance is generally attributed to oceanographic features associated with warm waters, such as a shallow mixed layer, high light regimes and oligotrophic nutrient conditions, rather than to a direct physiological response to the temperature itself (Hood et al., 2004). Nevertheless, it was recently demonstrated that the Trichodesmium strain IMS-101 are adapted to optimum growth temperatures of between 24 and $30^{\circ} \mathrm{C}$ tolerating temperatures from 20 to $34^{\circ} \mathrm{C}$ (Breitbarth et al., 2007). Thus, as suggested by Capone et al. (1997), seawater temperature sets a physiological constraint on the geographical distribution of Trichodesmium (Breitbarth et al., 2007). Most of the numerous sea surface accumulations of Trichodesmium observed in the South western Pacific Ocean near New Caledonia occurred during the spring and early summer periods when temperatures were above $25^{\circ} \mathrm{C}$. Monthly, mean SST's reached a maximum of $25.1^{\circ} \mathrm{C}$ during summer at the $\mathrm{S}$-gyre station reaching 27.3 and $26.4^{\circ} \mathrm{C}$ at the SW and N-gyre Pacific stations, respectively. SST's were less than $25^{\circ} \mathrm{C}$ over a large part of the South Pacific gyre during the BIOSOPE cruise (Fig. 2e) and may explain the current absence of Trichodesmium in the SP gyre. 
Other $\mathrm{N}_{2}$ fixing organisms may not be affected by temperature. Indeed, $\mathrm{N}_{2}$ fixers can be encountered at temperatures close to freezing (Zielke et al., 2002; Pandey et al., 2004). Then, another control for these species is needed to explain the low $\mathrm{N}_{2}$ fixation rates inside the gyre, or at least to explain why DIP is not completely exhausted from the upper layer.

\subsubsection{Fe availability}

Numerous experimental studies attribute a dominant role of Fe availability in the control of diazotroph growth (Paerl, 1994; Falkowski, 1997; Kustka et al., 2002; Mills et al., 2004). A high Fe requirement of the enzyme nitrogenase is believed to prevent $\mathrm{N}_{2}$ fixing organisms from alleviating widespread N limitation (Falkowski, 1997). Atmospheric input of dust, which is highly enriched in Fe relative to other nutrients, plays a significant role in the distribution of Trichodesmium (Orcutt et al., 2001) and on the decoupling between N-P-Fe-Si biogeochemical cycles in the ocean (Karl, 2002). High rates of $\mathrm{N}_{2}$ fixation in the North Atlantic were considered to be the result of the unusually high growth rates of $\mathrm{N}_{2}$ fixers, stimulated by the high $\mathrm{Fe}$ availability (Wu et al., 2000; Deutsch et al., 2007). Contrary to the oceanic gyres situated in the Northern Hemisphere, Fe-rich dust deposition is extremely low in the South Pacific gyre (Wagener et al., 2008) and dissolved Fe concentrations of $0.13 \pm 0.03 \mathrm{nmoll}^{-1}$ inside the upper water $(0-80 \mathrm{~m})$ of the gyre (Blain et al., 2007) may prevent the development of $\mathrm{N}_{2}$ fixing organisms. Nevertheless, enrichment experiments showed that primary production was $\mathrm{N}$-limited at the S-gyre station and no $\mathrm{N}_{2}$ fixation was measured following dust, Fe and/or P additions (Bonnet et al., 2007). The lack of response could be related to sampling at a depth of $30 \mathrm{~m}$ depth using a peristaltic pump, a depth where $\mathrm{N}_{2}$ fixation rates were extremely low and close to the detection limit of the method.

\section{3 $\mathrm{P}$ availability and the ultimate control of $\mathrm{N}_{2}$ fixation in the tropical Pacific ocean}

Following the most probable temporal changes (over a few decades) for factors controlling $\mathrm{N}_{2}$ fixation, several scenarios have been considered for $\mathrm{N}$ input via $\mathrm{N}_{2}$ fixation and the ultimate $\mathrm{P}$ availability for the South Pacific Ocean:

\subsubsection{Increase in temperature}

The expected increase in temperature will increase stratification but is not likely to modify the upwelling intensity near the Chilean coast and thus, changes in $\mathrm{N}_{2}$ fixation will probably occur elsewhere. If the presence of Trichodemium spp. is controlled by seawater temperature, any increase in temperature will increase its distribution. Breitbarth et al. (2007) predicted an $11 \%$ areal increase of Trichodesmium's potential geographic distribution following a modelled SST increase of up to $3^{\circ} \mathrm{C}$ by 2090 , but a simultaneous decrease in the area characterized by optimum growth. High SSTs are predicted for the western Pacific which is a characteristic province for present-day Trichodesmium abundance (LaRoche and Breitbarth, 2005). In this area where Trichodesmium biomass is already controlled by $\mathrm{P}$ availability, no change in $\mathrm{N}_{2}$ fixation with increasing temperature is expected. Nevertheless, the increasing widespread high sea surface temperature is expected to increase the distribution area of Trichodesmium driving the system towards the ultimate $\mathrm{P}$ control over a larger area. An increasing trend in $\mathrm{N}_{2}$ fixation associated with a decreasing trend in $\mathrm{P}$ availability may therefore be expected in the South western ocean.

\subsubsection{Increase in Fe dust deposition}

The dominant external input of Fe to the surface of the open ocean is the transport of aeolian dust, from the great deserts of the world (Jickells et al., 2005) and this appears to be very sensitive to climate changes (Mahowald et al., 2006). The effect of dust/Fe in subtropical gyres is a reduction in Fe limitation on $\mathrm{N}_{2}$ fixation so increasing primary production (Falkowski et al., 1998). A higher Fe supply to the sea surface has been hypothesized to favour $\mathrm{N}_{2}$ fixation in the continentally influenced Atlantic Ocean (Wu et al., 2000) as well as in the South Western Pacific Ocean (Van Den Broeck et al., 2004) and probably the Mediterranean Sea (Bonnet and Guieu, 2006). The increasing atmospheric input of Fe in the Northern Hemisphere has been believed to cause the decreasing trend of $\mathrm{P}$ availability at the $\mathrm{N}$-gyre station ALOHA (Karl et al., 2001). A similar trend may be expected for the South Pacific.

\subsubsection{An extension of the geographical area of denitrifica-} tion

Deutsch et al. (2007) suggest that $\mathrm{N}_{2}$ fixation is closely coupled to the generation of $\mathrm{N}$-deficient waters in areas of denitrification (timescale of year to decades) and are mainly dependent on the N:P ratios of the water upwelled near the coast. As denitrification occurs mainly in suboxic zones with $\left[\mathrm{O}_{2}\right]<5 \mu \mathrm{mol} \mathrm{L}^{-1}$ (Codispoti et al., 2001), any change in the spread of these areas will have significant impact on the $\mathrm{N}_{2}$ fixation rate inside the gyres. The most probable future change is an extension of the geographical areas of denitrification. This will generate a higher volume of DIN deficient waters and consequently, according to Deutsch et al. (2007) a higher $\mathrm{N}_{2}$ fixation rate in the South Pacific and a strengthening control of the carbon cycle by $\mathrm{P}$ availability.

\section{Conclusions}

We found that $\mathrm{P}$ availability was largely above the level required for $\mathrm{P}$ limitation on $\mathrm{N}_{2}$ fixation in the South Pacific gyre. This is in contrast to recent observations in the SW Pacific Ocean over the same latitude. We suggest a geographical trend for limitation on $\mathrm{N}_{2}$ fixation, from $\mathrm{P}$ limitation in 
the West to temperature and/or Fe limitation in the central and South East Pacific Ocean. The South Pacific gyre can be considered a High P Low Chlorophyll (HPLC) oligotrophic area, which could potentially support high $\mathrm{N}_{2}$ fixation rates if the primary control temperature and/or Fe availability were alleviated. A decrease in $\mathrm{P}$ availability due to an increasing input of $\mathrm{N}$ by $\mathrm{N}_{2}$ fixation is the most probable decadal trend to occur following climate change.

As already mentioned by Deutsch et al. (2007), environmental controls on $\mathrm{N}_{2}$ fixation and thus its probable response to past and future climate change would be much clearer if we knew the geographic distribution of this process in the ocean. The poor correlation between their model output and our observations for $\mathrm{N}_{2}$ fixation in the South Pacific area emphasizes the importance of studying the geographical distribution of $\mathrm{N}_{2}$ fixation as well as the main factors controlling this process. Increased understanding of the factors controlling the growth and biomass of $\mathrm{N}_{2}$ fixing organisms is needed in the field in order to constrain the models.

Acknowledgements. The authors thank the crew of the $\mathrm{R} / \mathrm{V}$ L'Atalante for outstanding shipboard support operations. D. Tailliez and C. Bournot are warmly thanked for their efficient help in CTD rosette management and data processing, A. Sciandra for his leadership during the second leg and T. Lefevre for English correction. This is a contribution of the BIOSOPE project of the LEFE-CYBER program. This research was funded by the Centre National de la Recherche Scientifique (CNRS), the Institut des Sciences de l'Univers (INSU), the Centre National d'Etudes Spatiales (CNES), the European Space Agency (ESA), The National Aeronautics and Space Administration (NASA) and the Natural Sciences and Engineering Research Council of Canada (NSERC). This work is funded in part by the French Research and Education council. Data from the N-gyre station (ALOHA) originates from Hawaii Ocean Time-series observations supported by the U.S. National Science Foundation under Grant OCE- 0326616 and from the Gordon and Betty Moore Foundation.

Edited by: S.W.A. Naqvi

\section{References}

Ammerman, J. W., Hood, R. R., Case, D. A., and Cotner, J. B.: Phosphorus Deficiency in the Atlantic: An Emerging Paradigm, Oceanography. Eos Trans., 84, 169-170, 2003.

Berman-Frank, I., Cullen, J. T., Shaked, Y., Sherrell, R. M., and Falkowski, P. G.: Iron availability, cellular iron quotas, and nitrogen fixation, Trichodesmium. Limnology and Oceanography, 46, 1249-1260, 2001.

Bjorkman, K., Thomson-Bulldis, A. L., and Karl, D. M.: Phosphorus dynamics in the North Pacific subtropical gyre, Aquatic Microbial Ecology, Aquat. Microb. Ecol., 22, 185-198, 2000.

Bjorkman, K. M. and Karl, D. M.: Bioavailability of dissolved organic phosphorus in the euphotic zone at station ALOHA, North Pacific Subtropical Gyre, Limnol. Oceanogr., 48, 1049-1057, 2003.
Blain, S., Bonnet, S., and Guieu, C.: Dissolved iron distribution in the tropical and sub tropical South Eastern Pacific, Biogeosciences Discuss., 4, 2845-2875, 2007, http://www.biogeosciences-discuss.net/4/2845/2007/.

Bonnet, S. and Guieu, C.: Atmospheric forcing on the annual iron cycle in the western Mediterranean Sea: A 1-year survey, J. Geophys. Res.-Oceans., 111, C09010, doi:10.1029/2005JC003213, 2006.

Bonnet, S., Guieu, C., Bruyant, F., Prášil, O., Van Wambeke, F., Raimbault, P., Grob, C., Moutin, T., Gorbunov, M. Y., Zehr, J. P., Masquelier, S. M., Garczarek, L., and Claustre, H.: Nutrients limitation of primary productivity in the Southeast $\mathrm{Pa}$ cific (BIOSOPE cruise), Biogeosciences Discuss., 4, 2733-2759, 2007, http://www.biogeosciences-discuss.net/4/2733/2007/.

Breitbarth, E., Oschlies, A., and LaRoche, J.: Physiological constraints on the global distribution of Trichodesmium - effect of temperature on diazotrophy, Biogeosciences, 4, 53-61, 2007, http://www.biogeosciences.net/4/53/2007/.

Broecker, W. S. and Peng, T. H.: Tracers in the sea, LamontDoherty Geological Observatory, Columbia University, 690 pp., 1982.

Capone, D. G. and Knapp, A. N.: Oceanography - A marine nitrogen cycle fix?, Nature, 445, 159-160, 2007.

Capone, D. G., Zehr, J. P., Paerl, H. W., Bergman, B., and Carpenter, E. J.: Trichodesmium, a globally significant marine cyanobacterium, Science, 276, 1221-1229, 1997.

Carpenter, E. J., Subramaniam, A., and Capone, D. G.: Biomass and primary productivity of the cyanobacterium Trichodesmium spp. in the tropical N Atlantic ocean, Deep-Sea Res. Part I - Oceanographic Research Papers, 51, 173-203, 2004.

Cembella, A. D., Antia, N. J., and Harrison, P. J.: The Utilization of Inorganic and Organic Phosphorus-Compounds as Nutrients by Eukaryotic Microalgae - a Multidisciplinary Perspective. 1. Crc Critical Reviews, Microbiology, 10, 317-391, 1984.

Chen, Y. L. L., Chen, H. Y., and Lin, Y. H.: Distribution and downward flux of Trichodesmium in the South China Sea as influenced by the transport from the Kuroshio Current, Mar. Ecol.Prog. Ser., 259, 47-57, 2003.

Clark, L. L., Ingall, E. D., and Benner, R.: Marine phosphorus is selectively remineralized, Nature, 393, 426-426, 1998.

Claustre, H. and Maritorena, S.: The many shades of ocean blue, Science, 302, 1514-1515, 2003.

Codispoti, L. A. and Richards, F. A.: Analysis of Horizontal Regime of Denitrification in Eastern Tropical North Pacific, Limnol. Oceanogr., 21, 379-388, 1976.

Codispoti, L. A., Brandes, J. A., Christensen, J. P., Devol, A. H., Naqvi, S. W. A., Paerl, H. W., and Yoshinari, T.: The oceanic fixed nitrogen and nitrous oxide budgets: Moving targets as we enter the anthropocene?, Sci. Mar., 65, 85-105, 2001.

Cotner, J. B., Ammerman, J. W., Peele, E. R., and Bentzen, E.: Phosphorus-limited bacterioplankton growth in the Sargasso Sea, Aquat. Microb. Ecol., 13, 141-149, 1997.

Davis, C. S. and McGillicuddy, D. J.: Transatlantic abundance of the N-2-fixing colonial cyanobacterium Trichodesmium, Science, 312, 1517-1520, 2006.

Deutsch, C., Sarmiento, J. L., Sigman, D. M., Gruber, N., and Dunne, J. P.: Spatial coupling of nitrogen inputs and losses in the ocean, Nature, 445, 163-167, 2007. 
Dore, J. E., Brum, J. R., Tupas, L. M., and Karl, D. M.: Seasonal and interannual variability in sources of nitrogen supporting export in the oligotrophic subtropical North Pacific Ocean, Limnol. Oceanogr., 47, 1595-1607, 2002.

Dugdale, R. C. and Wilkerson, F. P.: The Use of ${ }^{15} \mathrm{~N}$ to Measure Nitrogen Uptake in Eutrophic Oceans - Experimental Considerations, Limnol. Oceanogr., 31, 673-689, 1986.

Duhamel, S., Moutin, T., Van Wambeke, F., Van Mooy, B., Rimmelin, P., Raimbault, P., and Claustre, H.: Growth and specific Puptake rates of bacterial and phytoplanktonic communities in the Southeast Pacific (BIOSOPE cruise), Biogeosciences, 4, 941956, 2007, http://www.biogeosciences.net/4/941/2007/.

Dupouy, C., Neveux, J., Subramaniam, A., Mulholland, M. R., Montoya, J. P., Campbell, L., Carpenter, E. J., and Capone, D. G.: Satellite Captures Trichodesmium Blooms in the southwestern Tropical Pacific, EOS, 81, 13-16, 2000.

Dyhrman, S. T., Chappell, P. D., Haley, S. T., Moffett, J. W., Orchard, E. D., Waterbury, J. B., and Webb, E. A.: Phosphonate utilization by the globally important marine diazotroph Trichodesmium, Nature, 439, 68-71, 2006.

Falcon, L. I., Carpenter, E. J., Cipriano, F., Bergman, B., and Capone, D. G.: $\mathrm{N}_{2}$ fixation by unicellular bacterioplankton from the Atlantic and Pacific oceans: Phylogeny and in situ rates, Appl. Environ. Microb., 70, 765-770, 2004.

Falkowski, P. G.: Evolution of the nitrogen cycle and its influence on the biological sequestration of $\mathrm{CO}_{2}$ in the ocean, Nature, 387 , 272-275, 1997.

Falkowski, P. G., Barber, R. T., and Smetacek, V.: Biogeochemical controls and feedbacks on ocean primary production, Science, 281, 200-206, 1998

Fennel, K., Spitz, Y. H., Letelier, R. M., Abbott, M. R., and Karl, D. M.: A deterministic model for $\mathrm{N}_{2}$ fixation at stn. ALOHA in the subtropical North Pacific Ocean, Deep-Sea Research Part Ii-Topical Studies, Oceanography, 49, 149-174, 2002.

Fu, F. X. and Bell, P. R. F.: Factors affecting $\mathrm{N}_{2}$ fixation by the cyanobacterium Trichodesmium sp GBR-TRLI101, Fems Microbiol. Ecol., 45, 203-209, 2003.

Garcia, N., Raimbault, P., and Sandroni, V.: Seasonal nitrogen fixation and primary production in the Southwest Pacific: nanoplankton diazotrophy and transfer of nitrogen to picoplankton organisms, Mar. Ecol.-Prog. Ser., 343, 25-33, 2007.

Golterman, H. L. and de Oude, N. T.: Eutrophication of Lakes, Rivers and Coastal Seas, in: The Handbook of Environmental Chemistry, edited by: Hutzinger, O., Springer-Verlag, Berlin, 79-124., 1991

Gruber, N.: The dynamics of the marine nitrogen cycle and its influence on atmospheric $\mathrm{CO}_{2}$, The ocean carbon cycle and climate, Kluwer Academic, 97-148, 2004

Hood, R. R., Coles, V. J., and Capone, D. G.: Modeling the distribution of Trichodesmium and nitrogen fixation in the Atlantic Ocean, J. Geophys. Res.-Oceans, 109, C06007, doi:10.1029/2002JC001754, 2004.

Jickells, T. D., An, Z. S., Andersen, K. K., Baker, A. R., Bergametti, G., Brooks, N., Cao, J. J., Boyd, P. W., Duce, R. A., Hunter, K. A., Kawahata, H., Kubilay, N., laRoche, J., Liss, P. S., Mahowald, N., Prospero, J. M., Ridgwell, A. J., Tegen, I., and Torres, R.: Global iron connections between desert dust, ocean biogeochemistry and climate, Science, 308, 67-71, 2005.
Karl, D., Letelier, R., Tupas, L., Dore, J., Christian, J., and Hebel, D.: The role of nitrogen fixation in biogeochemical cycling in the subtropical North Pacific Ocean, Nature, 388, 533-538, 1997.

Karl, D. M.: Nutrient dynamics in the deep blue sea, Trends in Microbiology, Trends Microbiol., 10, 410-418, 2002.

Karl, D. M.: The marine phosphorus cycle, in: Manual of Environmental Microbiology, Third Edition, edited by: Hurst C. J. et al., American Society for Microbiology, Washington D.C., 523539, 2007.

Karl, D. M., Bidigare, R. R., Church, M. J., Dore, J. E., Letelier, R. M., Mahaffey, C., and Zehr, J.: The nitrogen cycle in the North Pacific trades biome: An evolving paradigm, edited by: Capone, D. G., Carpenter, E. J., Mulholland, M. and Bronk, D. A., Nitrogen in the Marine Environment, New York, Academic Press., in press.

Karl, D. M., Bjorkman, K. M., Dore, J. E., Fujieki, L., Hebel, D. V., Houlihan, T., Letelier, R. M., and Tupas, L. M.: Ecological nitrogen-to-phosphorus stoichiometry at station ALOHA, DeepSea Research Part Ii-Topical Studies in Oceanography, Deep-Sea Res. Part II-Top, Stud. Oceanogr., 48, 1529-1566, 2001.

Kolowith, L. C., Ingall, E. D., and Benner, R.: Composition and cycling of marine organic phosphorus, Limnol. Oceanogr., 46, 309-320, 2001.

Kustka, A., Carpenter, E. J., and Sanudo-Wilhelmy, S. A.: Iron and marine nitrogen fixation: progress and future directions, Res. Microbiol., 153, 255-262, 2002.

Labry, C., Herbland, A., and Delmas, D.: The role of phosphorus on planktonic production of the Gironde plume waters in the Bay of Biscay, J. Plankton Res., 24, 97-117, 2002.

LaRoche, J. and Breitbarth, E.: Importance of the diazotrophs as a source of new nitrogen in the ocean, J. Sea Res., 53, 67-91, 2005.

Levitan, O., Rosenberg, G., Setlik, I., Setlikova, E., Grigel, J., Klepetar, J., Prasil, O., and Berman-Frank, I.: Elevated $\mathrm{CO}_{2}$ enhances nitrogen fixation and growth in the marine cyanobacterium Trichodesmium, Glob. Change Biol., 13, 531-538, 2007.

Lucotte, M. and Danglejan, B.: Processes Controlling Phosphate Adsorption by Iron Hydroxides in Estuaries, Chem. Geol., 67, 75-83, 1988.

Lugomela, C., Lyimo, T. J., Bryceson, I., Semesi, A. K., and Bergman, B.: Trichodesmium in coastal waters of Tanzania: diversity, seasonality, nitrogen and carbon fixation, Hydrobiologia, 477, 1-13, 2002.

Mahowald, N. M., Muhs, D. R., Levis, S., Rasch, P. J., Yoshioka, M., Zender, C. S., and Luo, C.: Change in atmospheric mineral aerosols in response to climate: Last glacial period, preindustrial, modern, and doubled carbon dioxide climates, J. Geophys. Res.Atmos., 111, 2006.

Meybeck, M.: C, N, P and S in rivers: from sources to global in: inputs, Interaction of $\mathrm{C}, \mathrm{N}, \mathrm{P}$ and $\mathrm{S}$ biogeochemical cycles and global change, edited by: Wollast, F. T. M. R. and Chou, L., Springer Verlag, 163-193, 1993.

Mills, M. M., Ridame, C., Davey, M., La Roche, J., and Geider, R. J.: Iron and phosphorus co-limit nitrogen fixation in the eastern tropical North Atlantic, Nature, 429, 292-294, 2004.

Montoya, J. P., Voss, M., Kahler, P., and Capone, D. G.: A simple, high-precision, high-sensitivity tracer assay for $\mathrm{N}_{2}$ fixation, Appl. Environ. Microb., 62, 986-993, 1996.

Morel, A., Gentili, B., Claustre, H., Babin, M., Bricaud, A., Ras, 
J., and Tieche, F.: Optical properties of the "clearest" natural waters, Limnol. Oceanogr., 52, 217-229, 2007.

Moutin, T.: Cycle biogéochimique du phosphate: rôle dans le contrôle de la production planctonique et conséquence sur l'exportation du carbone de la couche éclairée vers l'océan profond, Océanis, 36, 643-660, 2000.

Moutin, T., Raimbault, P., Golterman, H. L., and Coste, B.: The input of nutrients by the Rhone river into the Mediterranean Sea: Recent observations and comparison with earlier data, Hydrobiologia, 374, 237-246, 1998.

Moutin, T., Van Den Broeck, N., Beker, B., Dupouy, C., Rimmelin, P., and Le Bouteiller, A.: Phosphate availability controls Trichodesmium spp. biomass in the SW Pacific Ocean, Mar. Ecol.Prog. Ser., 297, 15-21, 2005.

Moutin, T., Thingstad, T. F., Van Wambeke, F., Marie, D., Slawyk, G., Raimbault, P., and Claustre, H.: Does competition for nanomolar phosphate supply explain the predominance of the cyanobacterium Synechococcus?, Limnol. Oceanogr., 47, 15621567, 2002.

Needoba, J. A., Foster, R. A., Sakamoto, C., Zehr, J. P., and Johnson, K. S.: Nitrogen fixation by unicellular diazotrophic cyanobacteria in the temperate oligotrophic North Pacific Ocean, Limnol. Oceanogr., 52, 1317-1327, 2007.

Orcutt, K. M., Lipschultz, F., Gundersen, K., Arimoto, R., Michaels, A. F., Knap, A. H., and Gallon, J. R.: A seasonal study of the significance of $\mathrm{N}_{2}$ fixation by Trichodesmium spp. at the Bermuda Atlantic Time-series Study (BATS) site, Deep-Sea Res. Part II-Topical Studies, Oceanography, 48, 1583-1608, 2001.

Paerl, H. W., Prufert-Bebout, L. E., and Guo, C.: Iron-stimulated $\mathrm{N}_{2}$ fixation and growth in Natural and Cltured Populations of the Planktonic Marine Cyanobacteria Trichodesmium spp., Appl. Environ. Microb., 60, 1044-1047, 1994.

Pandey, K. D., Shukla, S. P., Shukla, P. N., Giri, D. D., Singh, J. S., Singh, P., and Kashyap, A. K.: Cyanobacteria in Antarctica: Ecology, physiology and cold adaptation, Cell. Mol. Biol., 50, 575-584, 2004.

Paytan, A. and McLaughlin, K.: The oceanic phosphorus cycle, Chem. Rev., 107, 563-576, 2007.

Perry, M. J. and Eppley, R. W.: Phosphate-Uptake by Phytoplankton in the Central North Pacific-Ocean, Deep-Sea Res. Part aOceanographic Research Papers, 28, 39-49, 1981.

Pujopay, M. and Raimbault, P.: Improvement of the Wet-Oxidation Procedure for Simultaneous Determination of Particulate Organic Nitrogen and Phosphorus Collected on Filters, Mar. Ecol.Prog. Ser., 105, 203-207, 1994.

Raimbault, P. and Garcia, N.: Carbon and nitrogen uptake in the South Pacific Ocean: evidence for efficient dinitrogen fixation and regenerated production leading to large accumulation of dissolved organic matter in nitrogen-depleted waters, Biogeosciences Discuss., 4, 3531-3579, 2007, http://www.biogeosciences-discuss.net/4/3531/2007/.

Raimbault, P., Slawyk, G., Coste, B., and Fry, J.: Feasibility of Using an Automated Colorimetric Procedure for the Determination of Seawater Nitrate in the 0 to $100 \mathrm{Nm}$ Range - Examples from Field and Culture, Mar. Biol., 104, 347-351, 1990.

Ras, J., Claustre, H., and Uitz, J.: Spatial variability of phytoplankton pigment distributions in the Subtropical South Pacific Ocean: comparison between in situ and predicted data, Biogeosciences Discuss., 4, 3409-3451, 2007, http://www.biogeosciences-discuss.net/4/3409/2007/.

Redfield, A. C.: On the proportions of organic derivatives in sea water and their relation to the composition of plankton, in: James Johnstone Memorial Volume, edited by: Daniel, R. J., University Press, 176-192, 1934.

Redfield, A. C., Ketchum, B. H., and Richards, F. A.: The influence of organisms on the composition of sea-water, in: THE SEA, Ideas and Observations on Progress in the Study of the Seas, edited by: Hill, M. N., Interscience publishers a division of John Wiley and Sons, 26-77, 1963.

Rimmelin, P. and Moutin, T.: Re-examination of the MAGIC method to determine low orthophosphate concentration in seawater, Anal. Chim. Acta, 548, 174-182, 2005.

Sanudo-Wilhelmy, S. A., Kustka, A. B., Gobler, C. J., Hutchins, D. A., Yang, M., Lwiza, K., Burns, J., Capone, D. G., Raven, J. A., and Carpenter, E. J.: Phosphorus limitation of nitrogen fixation by Trichodesmium in the central Atlantic Ocean, Nature, 411, 66-69, 2001.

Schlitzer, R.: Interactive analysis and visualization of geoscience data with Ocean Data View, Computers and Geosciences, 28, 1211-1218, 2002.

Staal, M., Meysman, F. J. R., and Stal, L. J.: Temperature excludes $\mathrm{N}$-2-fixing heterocystous cyanobacteria in the tropical oceans, Nature, 425, 504-507, 2003.

Strickland, J. D. H. and Parsons, T. R.: A practical handbook of seawater analysis, 2nd ed., Bull. Fish. Res. Bd. Can., 310 pp., 1972.

Tagliabue, A., Bopp, L., and Aumont, O.: Ocean biogeochemistry exhibits contrasting responses to a large scale reduction in dust deposition, Biogeosciences, 5, 11-24, 2008, http://www.biogeosciences.net/5/11/2008/.

Tanaka, T., Henriksen, P., Lignell, R., Olli, K., Seppala, J., Tamminen, T., and Thingstad, T. F.: Specific Affinity for Phosphate Uptake and Specific Alkaline Phosphatase Activity as Diagnostic Tools for Detecting Phosphorus-limited Phytoplankton and Bacteria, Estuaries Coasts, 29, 1226-1241, 2006.

Thingstad, T. F., Skjoldal, E. F., and Bohne, R. A.: Phosphorus Cycling and Algal-Bacterial Competition in Sandsfjord, Western Norway, Mar. Ecol.-Prog. Ser., 99, 239-259, 1993.

Tréguer, P. and LeCorre, P.: Manuel d'analyse des sels nutritifs dans l'eau de mer (Utilisation de l'autoAnalyseur II), Université de Bretagne Occidentale, Laboratoire d'Océanographie chimique, 110, 1975.

Tyrrell, T.: The relative influences of nitrogen and phosphorus on oceanic primary production, Nature, 400, 525-531, 1999.

Van Den Broeck, N. and Moutin, T.: Phosphate in the sediments of the Gulf of Lions (NW Mediterranean Sea), relationship with input by the river Rhone, Hydrobiologia, 472, 85-94, 2002.

Van Den Broeck, N., Moutin, T., Rodier, M., and Le Bouteiller, A.: Seasonal variations of phosphate availability in the SW Pacific Ocean near New Caledonia, Mar. Ecol.-Prog. Ser., 268, 1-12, 2004.

Van Wambeke, F., Obernosterer, I., Moutin, T., Duhamel, S., Ulloa, O., and Claustre, H.: Heterotrophic bacterial production in the South East Pacific: longitudinal trends and coupling with primary production, Biogeosciences Discuss., 4, 2761-2791, 2007 , http://www.biogeosciences-discuss.net/4/2761/2007/.

Wagener, T., Guieu, C., Losno, R., Bonnet, S., and Mahowald, N.: Revisiting atmospheric dust export to the South Hemisphere 
ocean, Global Biogeochem. Cy., doi:10.1029/2007GB002984, in press, 2008.

Wu, J. F., Sunda, W., Boyle, E. A., and Karl, D. M.: Phosphate depletion in the western North Atlantic Ocean, Science, 289, 759$762,2000$.

Zehr, J. P., Waterbury, J. B., Turner, P. J., Montoya, J. P., Omoregie, E., Steward, G. F., Hansen, A., and Karl, D. M.: Unicellular cyanobacteria fix $\mathrm{N}_{2}$ in the subtropical North Pacific Ocean, Nature, 412, 635-638, 2001.

Zehr, J. P., Montoya, J. P., Jenkins, B. D., Hewson, I., Mondragon, E., Short, C. M., Church, M. J., Hansen, A., and Karl, D. M.: Experiments linking nitrogenase gene expression to nitrogen fixation in the North Pacific subtropical gyre, Limnol. Oceanogr., 52, 169-183, 2007.
Zielke, M., Ekker, A. S., Olsen, R. A., Spjelkavik, S., and Solheim, B.: The influence of abiotic factors on biological nitrogen fixation in different types of vegetation in the High Arctic, Svalbard, Arct. Antarct. Alp. Res., 34, 293-299, 2002.

Zohary, T. and Robarts, R. D.: Experimental study of microbial P limitation in the eastern Mediterranean, Limnol. Oceanogr., 43, 387-395, 1998. 